\title{
The Effect of Family Support, Transfusion Compliance and Self-Efficacy on the Quality of Life of Children With Thalassemia lyam Mariam
}

Study Program of Bachelor Nursing, Sekolah Tinggi IImu Kesehatan Sukabumi Indonesia

\section{ORCID}

lyam Mariam: https://orcid.org/0000-0002-6225-0449

Corresponding Author: lyam Mariam; email: johanbudhiana@dosen.stikesmi.ac.id

Published: 7 February 2022

Publishing services provided by Knowledge E

(c) Iyam Mariam. This article is distributed under the terms of the Creative Commons

Attribution License, which permits unrestricted use and redistribution provided that the original author and source are credited.

Selection and Peer-review under the responsibility of the IVCN Conference Committee.

\section{G OPEN ACCESS}

Abstract. Thalassemia is a chronic disease that can affect quality of life. The purpose of this study was to determine the effect of family support, transfusion compliance and self-efficacy on the quality of life of children with thalassemia. This research was correlational with a cross-sectional approach. The sample consisted of 45 people. Data were collected using questionnaires, and statistical analysis consisted of descriptive data analysis of respondents' characteristics, univariate analysis of each variable, simple linear regression analysis and multiple linear regression analysis. The results showed that family support affected quality of life $(b=0.628, p=0.009)$, transfusion compliance affected quality of life $(b=7.294, p=0.048)$, and self-efficacy affected quality of life $(b=0.374, p=0.038)$. Also, family support, transfusion compliance and self-efficacy simultaneously affected the quality of life of children with thalassemia at Bhayangkara Setukpa Hospital, Sukabumi City $(p<0.001)$.

Keywords: family support, transfusion compliance, self-efficacy, thalassemia, quality of life

\section{Introduction}

Thalassemia is a chronic disease that causes serious public health problems in the world. Although not contagious, chronic diseases can cause high mortality rates, besides that the healing process takes a long time and is permanent [1].

Based on data from the World Health Organization, the prevalence of thalassemia in various countries is quite high, such as Italy $10 \%$, Greece $5-10 \%$, China $2 \%$, India $1-5 \%$, if depicted on a world map, it seems to form a belt (thalassemic belt), of which Indonesia is included [2].

In Indonesia, based on data from Yayasan Thalasemia Indonesia, there has been an increase in thalassemia cases since the last five years. In 2012 there were 4,896 cases and in 2017 it continued to increase to 8,616 cases. West Java has the highest number of thalassemia sufferers in Indonesia as many as 3,264 people with thalassemia at the end of 2017 [3]. 
Thalassemia is a hereditary disease that attacks the blood system, where hemoglobin is not produced normally in the body. This disease occurs due to mutations in the alpha gene or beta gene that encodes a protein in forming the composition of blood hemoglobin [4]. Thalassemia is a chronic disease that occurs in children. According to Nurarif (2013), thalassemia is a syndrome of inherited disorders that enter into hemoglobinopathy, resulting in impaired hemoglobin synthesis due to mutations in or near genes [5].

Thalassemia consists of two groups including: 1) thalassemia minor, which is a disease state of the mildest clinical symptoms (heterozygous form) and 2) thalassemia major, a disease state of the most severe clinical symptoms (homozygous form) and is highly dependent on transfusion. The heterozygous form is inherited from one parent with thalassemia, while the homozygous form is inherited from both parents with thalassemia [6].

Thalassemia is a chronic disease that can actually affect the quality of life of the sufferer. Patients with thalassemia are required to receive lifelong care that affects the child's biological, psychological, social and spiritual conditions. Conditions that occur in children can reduce their quality of life [7].

The quality of life of people with thalassemia can be affected due to several things, such as physical, psychological, social problems, frequent visits to the hospital, medical procedures that cause pain, unclear future life, thoughts about death coupled with a lack of family support [8].

Another factor that affects a person's quality of life is his compliance to treatment. Compliance in carrying out regular transfusion therapy in thalassemia patients makes it possible to maintain an $\mathrm{Hb}$ of about $10 \mathrm{~g} \%$ which will affect the growth and development of children for the better. In addition, it can also suppress endogenous erythropoiesis which is useful in avoiding ineffective erythropoiesis so that hepatosplenomegaly can be reduced due to extramedullary hematopoiesis, bone deformities and heart enlargement. Finally, children with thalassemia can feel life almost like a normal child and will certainly improve their quality of life [9].

A person's self-efficacy is also one of the factors that affect the quality of life. The relationship between self-efficacy and a person's quality of life can be seen in several processes. Based on the motivation process, the higher the self-efficacy of a person, the higher the motivation to improve and maintain healthy behavior in life. Based on the affective process, self-efficacy can affect the stressor so that it affects the level of anxiety experienced. Based on the selection process, self-efficacy will affect the behavior formed by a person in carrying out daily activities in their environment [10]. 
Increasing self-efficacy can be an alternative used in improving the quality of life of patients with chronic diseases, especially those with long treatment processes, one of which is thalassemia [1].

Bhayangkara Setukpa Hospital Sukabumi City has excellent services in the treatment of thalassemia disease. One of the facilities in the treatment of thalassemia disease at Bhayangkara Setukpa Hospital Sukabumi City is treatment (blood transfusion) which has been around since 2010. Treatment (blood transfusion) at Bhayangkara Setukpa Hospital Sukabumi City is carried out for some time, including once a month, 2 once a week and once every 3 weeks depending on the severity of the patient's illness.

From the description above, the researcher is interested in conducting a research entitled The Effect of Family Support, Transfusion Compliance and Self-efficacy on the Quality of Life of Children with Thalassemia at Bhayangkara Setukpa Hospital, Sukabumi City.

\section{Methods}

The type this research is correlational research with cross sectional approach. The population in this research were all pediatric patients with thalassemia at Bhayangkara Setukpa Hospital, Sukabumi City with a sample of 45 people. The inclusion criteria used in this research included children with thalassemia aged 5-11 years, willing to be respondents and undergoing transfusion visits. The exclusion criteria used in this research were children with thalassemia who were treated intensively during the research. The sampling technique used was total sampling.

Data retrieval in this research using a questionnaire and statistical analysis used is descriptive data analysis of respondents' characteristics, univariate analysis of each variable, simple linear regression analysis and multiple linear regression analysis.

\section{Result}

Based on table 1 shows most of the respondents aged 8-10 years as many as 31 people (68.9\%), female sex as many as 26 people (57.8\%), elementary school education as many as 44 people (97.8\%), long suffering from thalassemia 8-12 years as many as 29 people (64.4\%), assistants to the hospital were mothers as many as 34 people (75.6\%), assistants aged $26-45$ years as many as 32 people (71.1\%), female companions as many as 39 people (86.7\%) and companions with the latest high school education as many as 19 people $(42.2 \%)$. 
Based on table 2 shows that the average value of family support is 45.87 (7.707), on transfusion compliance an average value of $0.82(0.387)$ is obtained, on self-efficacy the average value is 51.58 (10.116), on the quality of life obtained an average value 48.67 (12,347).

Based on table 3 shows that family support affects quality of life ( $b=0.628, p=0.009)$, transfusion compliance affects quality of life $(b=7.294, p=0.048)$, and self-efficacy affects quality of life ( $b=0.374, p=0.038)$.

Based on table 4 shows that family support, transfusion compliance and self-efficacy affect the quality of life simultaneously $(p=0.000)$.

\section{Discussion}

\subsection{Family Support on Quality of Life}

Based on the results of the study, it shows that there is an effect of family support on quality of life. Research by Hardin and Dhila (2021) states that there is a relationship between family support and quality of life [11]. Another similar study is the research conducted by Rahayuningrum et al (2021) which states that there is a relationship between family support and quality of life [12]. Another research that supports is the research of Wang et al [13] which states that emotional support and decision support from the family are positively related to individual life satisfaction [13]. Research by Ae Ran and Kyeong-Sook [14] also states that quality of life is positively correlated with family support [14].

Friedman explained that family support is an assistance from the family to one of his family members. This assistance can be in the form of providing a sense of comfort, both physically and psychologically when one of the family members is experiencing difficulties or pain [11]. In self-care activities and social activities, families need to provide support to individuals in helping and controlling individuals in making decisions, one of which is in choosing the necessary health services [12].

The World Health Organization states that one of the domains that can be used to measure an individual's quality of life is their social relationships, such as social relationships with family. Taylor explained that when individuals receive high family support, individuals will experience low stress and perform better coping mechanisms. Conversely, when the family support received by the individual is low, the individual tends to be able to perform poor coping mechanisms in dealing with existing stressors [11]. 
The higher the family support received by the individual for their the quality of life better. Conversely, the lower the family support, the lower the quality of life [15]. Family support tends to make individuals feel better, feel safe and feel accepted by their families. This situation will make individuals feel prosperous, enjoy their lives more and will ultimately affect their quality of life [12]. In addition, according to a theory regarding support/efficacy, it is also explained that social relationships such as well-established family relationships will have an influence on individual self-efficacy and self-esteem, so that individuals have satisfaction in their lives [13].

Effective participation of families in children with chronic diseases such as thalassemia is needed. In dealing with illness, children need good listeners and can be trusted like family. In addition, good family support can make children not feel alone in dealing with their illness and help children undergo a series of treatments that need to be carried out more optimally. Family support greatly facilitates children in finding strength to face their chronic conditions [16].

\subsection{Transfusion Compliance on Quality of Life}

Based on the results of the study, it showed that there was an effect of transfusion compliance on quality of life. Rahman et al's research [17] states that compliance is the most dominant variable that is significantly related to quality of life [17]. Another supporting study is the research conducted by Chalik et al [18] which states that medication compliance is independently associated with quality of life [18]. Another study that is in line is the study of [19] which states that good quality of life in individuals has a significant relationship with medication compliance [19].

Compliance is the active and voluntary participation of individuals in managing their disease, then health workers and individuals each have roles and duties so that they can be jointly involved in disease management [17]. Compliance can be seen from the patient's behavior in complying with the provisions given by health professionals in managing their illness [20].

Compliance to treatment plays an important role in the long-term management of chronic diseases [19]. Compliance is one of the main principles in dealing with chronic diseases such as thalassemia [21]. Compliance with treatment therapy can be an important thing that needs to be considered because it will be carried out for life by thalassemia sufferers. The more obedient the individual performs treatment therapy, the higher the quality of life he has [22]. 
TABLE 1: Characteristics of Respondents

\begin{tabular}{|c|c|c|}
\hline Characteristics & f & $\%$ \\
\hline \multicolumn{3}{|l|}{ Child Identity } \\
\hline \multicolumn{3}{|c|}{ Age } \\
\hline $8-10$ years & 31 & 68.9 \\
\hline $11-12$ years & 14 & 31.1 \\
\hline \multicolumn{3}{|c|}{ Gender } \\
\hline Man & 19 & 42.2 \\
\hline Woman & 26 & 57.8 \\
\hline \multicolumn{3}{|c|}{ Education } \\
\hline Primary school & 44 & 97.8 \\
\hline Dropout & 1 & 2.2 \\
\hline $\begin{array}{l}\text { Long Suffering } \\
\text { Thalassemia }\end{array}$ & & \\
\hline 4-7 years & 16 & 35.6 \\
\hline $8-12$ years & 29 & 64.4 \\
\hline \multicolumn{3}{|c|}{ Companion to the Hospital } \\
\hline Father & 3 & 6.7 \\
\hline Mother & 34 & 75.6 \\
\hline Other & 8 & 17.8 \\
\hline \multicolumn{3}{|l|}{ Companion Identity } \\
\hline \multicolumn{3}{|c|}{ Age } \\
\hline $12-25$ years & 2 & 4.4 \\
\hline $26-45$ years & 32 & 71.1 \\
\hline $46-65$ years & 11 & 24.4 \\
\hline \multicolumn{3}{|c|}{ Gender } \\
\hline Man & 6 & 13,3 \\
\hline Woman & 39 & 86,7 \\
\hline \multicolumn{3}{|c|}{ Last education } \\
\hline No school & 1 & 2.2 \\
\hline Primary school & 11 & 24.4 \\
\hline Junior High School & 9 & 20.0 \\
\hline Senior High School & 19 & 42.2 \\
\hline College & 5 & 11.1 \\
\hline
\end{tabular}

TABLE 2: Univariate Analysis of Variables

\begin{tabular}{l|l|l|l|l|} 
Variable & Mean & $\begin{array}{l}\text { Standard } \\
\text { (SD) }\end{array}$ & $\begin{array}{l}\text { Deviation } \\
\text { Max }\end{array}$ & Min \\
\hline $\begin{array}{l}\text { Family Support } \\
\text { Transfusion }\end{array}$ & 45.87 & 7.707 & 69 & 36 \\
Compliance & 0.82 & 0.387 & 1 & 0 \\
\hline $\begin{array}{l}\text { Self-efficacy } \\
\text { Quality of Life }\end{array}$ & 51.58 & 10.116 & 80 & 35 \\
\hline & 48.67 & 12.347 & 79 & 29
\end{tabular}


TABLE 3: Simple Linear Regression

\begin{tabular}{|c|c|c|c|c|c|}
\hline \multirow[t]{2}{*}{ Variable } & \multicolumn{2}{|c|}{ Unstandardized Coefficients } & \multirow{2}{*}{$\begin{array}{l}\text { Standardized } \\
\text { Coefficients } \\
\text { Beta }\end{array}$} & \multirow[t]{2}{*}{$\mathbf{t}$} & \multirow{2}{*}{$\begin{array}{l}\text { P- } \\
\text { Value }\end{array}$} \\
\hline & Beta & Std.Error & & & \\
\hline (Constant) & -5.444 & 8.665 & & -0.628 & 0.533 \\
\hline Family Support & 0.628 & 0.228 & 0.392 & 2.758 & 0.009 \\
\hline Transfusion Compliance & 7.294 & 3.578 & 0.228 & 2.039 & 0.048 \\
\hline Self-efficacy & 0.374 & 0.174 & 0.307 & 2.145 & 0.038 \\
\hline
\end{tabular}

TABLE 4: Multiple linear regression

\begin{tabular}{|c|c|c|c|c|c|}
\hline & $\begin{array}{l}\text { Sum of } \\
\text { Squares }\end{array}$ & & Mean Square & $\mathbf{F}$ & $\begin{array}{l}\text { P- } \\
\text { Value }\end{array}$ \\
\hline Regression & 3370.457 & 3 & 1123.486 & 13.801 & 0.000 \\
\hline Residual & 3337.543 & 41 & 81.403 & & \\
\hline Total & 6708.000 & 44 & 1123.486 & & \\
\hline
\end{tabular}

Children with thalassemia need to maintain compliance with their transfusion. Transfusion is necessary to maintain a hemoglobin level of $9-10 \mathrm{~g} / \mathrm{dl}$ [9]. Transfusion compliance can reduce the risk of complications and can help thalassemia sufferers increase their life expectancy [21]. In addition, repeated transfusions will maintain health and provide energy for thalassemia sufferers to be able to carry out their daily activities [20]. This of course can affect their quality of life

In addition, transfusion compliance also affects the growth of individuals with thalassemia patients. This is because individuals with thalassemia can experience anemia and endocrine problems that will interfere with their growth process, such as having a short stature. In addition, Smelt \& Bare revealed that when transfusions are not carried out regularly or even stopped, it will have an impact on more fatal conditions and even death [9]. In this regard, compliance with transfusion can help normal growth and minimize complaints and impacts on children with thalassemia so that it can affect the improvement of their quality of life.

\subsection{Self-efficacy on Quality of Life}

Based on the results of the study, it shows that there is a relationship between selfefficacy and quality of life. [23] states that there is a significant relationship between self-efficacy and quality of life [23]. Another similar study is the research conducted by [24] which states that there is a relationship between self-efficacy and quality of life [24]. Another research that supports is the study of [25] which states that self-efficacy mediates the relationship between positivity and health-related quality of life [25]. 
Self-efficacy can be interpreted as an individual's belief in his ability to complete a task or face an event in accordance with the desired goal. Bandura explained that when individuals have high self-efficacy, they will not perceive the problems they face as obstacles or threats, but consider them as challenges that can be solved. In terms of health, self-efficacy is defined as the individual's ability to carry out rehabilitation and better adjustments in dealing with disease in order to improve health [26].

Kott said, good self-efficacy will make individuals see the problems they face from a positive side so that they influence individuals in determining the actions to be chosen. Wakhid, Estri \& Liyanovitasari revealed that good self-efficacy will give confidence to individuals to recover and help individuals accept their illness. Individuals will be easier to adapt to their circumstances, whether physically, psychologically, socially or environmentally. This can encourage the growth of motivation in individuals to improve their health conditions and ultimately an increase in their quality of life [24].

Increasing individual self-efficacy should be done to achieve a better quality of life. Caroline explained that when individuals have high self-efficacy, their ability to carry out physical activities and social functions will also be higher. Fathia also revealed that high self-efficacy tends to make individuals have a desire to develop themselves which will affect their quality of life. In addition, self-efficacy and self-care behavior have a positive relationship that will be beneficial in improving the quality of life [23].

Individuals who suffer from chronic diseases such as thalassemia will feel more of the impact of their illness so they tend to experience a decrease in quality of life [27]. In this case, self-efficacy can be used as a determining factor that can influence individuals in carrying out self-management to overcome this. High self-efficacy will affect the individual's perception when carrying out a series of treatments that can make him recover and be more controlled in dealing with his illness. In this regard, individuals will be more motivated to improve their ability to carry out daily activities, improve their health, self-confidence and welfare of their lives. This will also affect their quality of life [28].

\section{Conclusion}

There is a simultaneous effect of family support, transfusion compliance and self-efficacy on the quality of life of children with thalassemia at Bhayangkara Setukpa Hospital, Sukabumi City. 


\section{References}

[1] Afandi AT, Kurniyawan EH. Efektivitas self-efficacy terhadap kualitas hidup klien dengan diagnosa penyakit kronik. In Prosiding Seminar Nasional dan Workshop Publikasi IImiah; 2018;February 05 8p.

[2] Marnis D, Indriati G, Nauli FA. Hubungan tingkat pengetahuan dengan kualitas hidup anak thalasemia. Jurnal Keperawatan Sriwijaya. 2018;5(2):31-42.

[3] Kemenkes. Profil kesehatan Indonesia. Jakarta: Kementerian Kesehatan Indonesia; 2018.

[4] Rujito L, Lestari DWD, Aziz A, Faiza D. Sosialisasi thalassemia kepada guru biologi di banyumas: Upaya pencegahan terintegrasi melalui kurikulum sekolah. Jurnal Pengabdian Pada Masyarakat. 2018;3(1):1-6. https://doi.org/10.30653/002.201831.35

[5] Renylda R. kecemasan orang tua pada anak dengan thalasemia di poli anak rumah sakit umum daerah H. Abdul manap kota jambi tahun 2015. Jurnal IImiah Universitas Batanghari Jambi. 2018;18(1):110. https://doi.org/10.33087/jiubj.v18i1.438

[6] Hutahaen F, Hendrianingtyas M. Hubungan jumlah transfusi dengan kadar tsh pada thalassemia. Jurnal Kedokteran Diponegoro. 2017;6(2):558-566.

[7] Ray RL, Rahmawati F, Andhini D. Hubungan pengetahuan dan sikap orang tua dengan kualitas hidup anak penderita talasemia. Seminar Nasional Keperawatan. 2018;4(1):79-85.

[8] Anisawati LD. Dukungan orang tua dengan kualitas hidup anak penderita thalasemia. (Doctoral dissertation, STIKES Insan Cendekia Medika Jombang. 2017.

[9] Mustofa FL, Triswanti N, Rukmono P, Satriadi MF. Hubungan Kepatuhan transfusi darah terhadap pertumbuhan anak thalassemia di rumah singgah thalassemia bandar lampung. Jurnal Medika Malahayati. 2020;4(2):130-136.

[10] Shoufiah R. Hubungan faktor resiko dan karakteristik penderita dengan kejadian penyakit jantung koroner. Mahakam Nursing Journal. 2016;1(1):17-26.

[11] Hardin F, Dhila SN. Hubungan dukungan keluarga dengan kualitas hidup pasien dm di puskesmas lubuk begalung padang tahun 2019. Jurnal Kesehatan Lentera 'Aisyiyah. 2021;4(1):317-326.

[12] Rahayuningrum DC, Nofia V, Dewi RIS, Zulfianis M. Hubungan dukungan keluarga dengan kualitas hidup pasien skizofrenia. Jurnal Kesehatan Medika Saintika. 2021;11(2):282-289.

[13] Wang L, Yang L, Di X, Dai X. Family support, multidimensional health, and living satisfaction among the elderly: A case from Shaanxi province, China. 
International Journal of Environmental Research and Public Health. 2020;17(22):1-18. https://doi.org/10.3390/ijerph17228434

[14] Ae Ran P, Kyeong-Sook J. Influence of subjective health status, social activity and family support on subjective quality of life of elderly in a community. Journal of the Korean Contents Association. 2017;17(3):212-221.

[15] Irawan E, Hayati S, Purwaningsih D. Hubungan dukungan keluarga dengan kualitas hidup penderita kanker payudara. Jurnal Keperawatan BSI. 2017; Vol 5 No 2;121-129.

[16] Silva MEA, Moura FMA, Reichert APS, Collet N. Network and social support in children with chronic diseases: Understanding the child's perception. Texto \& Contexto Enfermagem. 2017;26(1):1-10. https://doi.org/10.1590/0104-07072017006980015

[17] Rahman HF, Yulia Y, Sukarmini L. Efikasi diri, kepatuhan, dan kualitas hidup pasien diabetes melitus tipe 2 (Self-efficacy, adherence, and quality of life of patients with type 2 diabetes). E-Jurnal Pustaka Kesehatan. 2017;5:108-113.

[18] Chalik R, Ahmad T, Hidayati H. Kepatuhan pengobatan dan kualitas hidup pada pasien hipertensi rawat jalan di rumah sakit X Kota Makassar. Media Farmasi. 2021:17(1):85. https://doi.org/10.32382/mf.v17i1.1983

[19] Majeed A, Rehman M, Hussain I, et al. The impact of treatment adherence on quality of life among type 2 diabetes mellitus patients - Findings from a cross-sectional study. Patient Preference and Adherence. 2021;15:475-481. https://doi.org/10.2147/PPA.S295012

[20] Hijriani H, Septiani NU. Hubungan kepatuhan tranfusi darah dan konsumsi kelasi besi terhadap pertumbuhan anak dengan thalasemia mayor correlation of compliance of blood transfusion and consumption of iron chelation on child growth with thalassemia major. Jurnal Kampus STIKes YPIB Majalengka. 2020;8(2):105-117.

[21] Ghorbanpoor M, Mirzaie M, Mirhaghjou SN, Roshan ZA. The relationship between psychosocial status and adherence to treatment regimen in adolescents with thalassemia. Journal of Holistic Nursing and Midwifery. 2020;30(2):78-85. https://doi.org/10.32598/jhnm.30.2.78

[22] Wati FR, Afiani N, Qodir A. Pasien hipertensi dengan penyerta diabetes mellitus. Media Husada Journal of Nursing Sciences. 2021;2:28-34.

[23] Welly W, Rahmi H. Self-efficacy dengan kualitas hidup pasien gagal ginjal kronik yang menjalani hemodialisa. Jurnal Keperawatan Abdurrab. 2021;5(1):38-44. https://doi.org/10.36341/jka.v5i1.1791

[24] Pongantung H, Anita F, Palango C, Manuel C. Hubungan self-efficacy dengan quality of life pada pasien sesudah stroke. Journal of Islamic Nursing. 2020;5(1):21. https://doi.org/10.24252/join.v5i1.13894 
[25] Tabernero C, Caprara GV, Gutiérrez-Domingo T, et al. Positivity and self-efficacy beliefs explaining health-related quality of life in cardiovascular patients. Psicothema. 2021;33(3):433-441. https://doi.org/10.7334/psicothema2020.476

[26] Brunes A, Hansen MB, Heir T. General self-efficacy in individuals with visual impairment compared with the general population. PLoS ONE. 2021;16( July):1-12. https://doi.org/10.1371/journal.pone.0254043

[27] Taheri P, Nooryan K, Karimi Z, Zoladl M. Effect of individual psychotherapy with a focus on self-efficacy on quality of life in patients with thalassemia major: A clinical trial. Journal of Clinical Care and Skills. 2020;1(2):49-54. https://doi.org/10.52547/jccs.1.2.49

[28] Susanti L, Murtaqib M, Kushariyadi K. Hubungan antara efikasi diri dengan kualitas hidup pasien hipertensi di wilayah kerja puskesmas silo jember. Pustaka Kesehatan. 2020;8(1):17. https://doi.org/10.19184/pk.v8i1.10891 